\title{
Health risk assessment by trace elements in an aquatic system in midwestern Brazil
}

\author{
Avaliação de risco à saúde por oligoelementos em um sistema aquático no centro-oeste do Brasill \\ Evaluación de riesgos para la salud por oligoelementos en un sistema acuático en el medio oeste de
}

Brasil

Received: 08/03/2021 | Reviewed: 08/07/2021 | Accept: 08/10/2021 | Published: 08/14/2021

Raylane Pereira Gomes

ORCID: https://orcid.org/0000-0001-8495-1361

Federal University of Goiás, Brazil

E-mail: raylanepgomes@gmail.com

Thais Reis Oliveira

ORCID: https://orcid.org/0000-0002-4979-8653

Federal University of Goiás, Brazil

E-mail: thaisreisoliveira@hotmail.com

Aline Rodrigues Gama

ORCID: https://orcid.org/0000-0003-2167-3872

Alfredo Nasser University Center, Brazil

E-mail: alinerodriguesgama15@gmail.com

Fernando Santos Lima

ORCID: https://orcid.org/0000-0002-3446-5776

Federal University of Goiás, Brazil

E-mail: fernando.amil@yahoo.com.br

José Daniel Gonçalves Vieira

ORCID: https://orcid.org/0000-0001-5434-4915

Federal University of Goiás, Brazil E-mail: jvieira@ufg.br

Thiago Lopes Rocha

ORCID: https://orcid.org/0000-0003-0551-6842

Federal University of Goiás, Brazil

E-mail: thiagorochabio20@ufg.br

Lilian Carla Carneiro

ORCID: https://orcid.org/0000-0003-4067-1506

Federal University of Goiás, Brazil

E-mail: carlacarneirolilian@gmail.com

\begin{abstract}
Water is an important asset for the maintenance of life and socioeconomic development. Aquatic environments have been anthropized, receiving a large polluting load, mainly from trace elements. This study investigates the occurrence of health risks caused by 15 trace elements in the surface water of João Leite stream. Health risk indices were evaluated as average daily dose (ADD), hazard quotient (HQ), hazard index and carcinogenic risk. The risk analysis to human health of the stream João Leite water, indicated that the $\mathrm{ADD}_{\text {ingestion }}$ for the adults had the highest for Fe $1.86 \mathrm{E}$ $00 \mu \mathrm{g} / \mathrm{kg} /$ day and lower value for Be $8.0 \mathrm{E}-05 \mu \mathrm{g} / \mathrm{kg} / \mathrm{day}$. On the other hand, of $\mathrm{ADD}_{\text {dermal }}$ the highest value was for Fe $5.02 \mathrm{E}-02 \mu \mathrm{g} / \mathrm{kg} / \mathrm{day}$ and, the smallest for $\mathrm{Sb} 1.54 \mathrm{E}-05 \mu \mathrm{g} / \mathrm{kg} /$ day. For children to $\mathrm{ADD}_{\text {ingestion }}$ obtained was obtained the highest Fe value $2.60 \mathrm{E}-00 \mu \mathrm{g} / \mathrm{kg} /$ day and smaller for Be $1.12 \mathrm{E}-04 \mu \mathrm{g} / \mathrm{kg} / \mathrm{day}$. For $\mathrm{ADD}_{\text {dermal }}$ the highest value was for $\mathrm{Fe} 8.58 \mathrm{E}-02 \mu \mathrm{g} / \mathrm{kg} /$ day and smaller for $\mathrm{Sb} 2.64 \mathrm{E}-05 \mu \mathrm{g} / \mathrm{kg} /$ day. HQ for adults ranged from 1.61E-05 to $2.97 \mathrm{E}-01$ for $\mathrm{HQ}_{\text {ingestion }}$ and 7.71E-06 to $1.01 \mathrm{E}-01$ for $\mathrm{HQ}_{\text {dermal }}$. For children 2.25E-05 to 3.74E-01 for HQ ingestion and $1.32 \mathrm{E}-05$ to $1.73 \mathrm{E}-01$ for $\mathrm{HQ}_{\mathrm{dermal}}$. The health risk assessment showed that for children, the trace elements present in water have a potentially adverse effect on non-carcinogenic health. The carcinogenic risks were unacceptable for both children and adults. Thus, it is recommended that the use of these waters be limited and that measures be taken to minimize pollution by trace elements.
\end{abstract}

Keywords: Water pollution; Metal; Non-carcinogenic risk; Cancer risk; Contamination.

\section{Resumo}

A água é um bem importante para a manutenção da vida e para o desenvolvimento socioeconômico. Os ambientes aquáticos vêm sendo antropizados, recebendo grande carga de poluente, principalmente de oligoelementos. Este estudo investiga a ocorrência de riscos à saúde causados por 15 oligoelementos nas águas superficiais do riacho João Leite. Os índices de risco à saúde foram avaliados como dose média diária (ADD), quociente de risco (HQ), índice de risco e risco carcinogênico. A análise de risco à saúde humana do riacho João Leite, indicou que a $\mathrm{ADD}_{\text {ingestão para os }}$ adultos teve maior para Fe 1,86E-00 $\mu \mathrm{g} / \mathrm{kg} / \mathrm{dia}$ e menor valor para Be 8,0E-05 $\mu \mathrm{g} / \mathrm{kg} / \mathrm{dia}$. Por outro lado, da 
$\mathrm{ADD}_{\text {dérmica }}$ o maior valor foi para Fe 5,02E-02 $\mu \mathrm{g} / \mathrm{kg} / \mathrm{dia}$ e o menor para Sb 1,54E-05 $\mu \mathrm{g} / \mathrm{kg} / \mathrm{dia}$. Para crianças com $\mathrm{ADD}_{\text {ingestão }}$ obtida com maior valor foi Fe 2,60E-00 $\mu \mathrm{g} / \mathrm{kg} /$ dia e menor para Be 1,12E-04 $\mu \mathrm{g} / \mathrm{kg} /$ dia. Para $\mathrm{ADD}_{\text {dérmica }} \mathrm{O}$ maior valor foi para Fe 8,58E-02 $\mu \mathrm{g} / \mathrm{kg} / \mathrm{dia}$ e menor para Sb 2,64E-05 $\mu \mathrm{g} / \mathrm{kg} / \mathrm{dia}$. HQ para adultos variou de 1,61E-05 a 2,97E-01 para HQ ingestião e 7,71E-06 a 1,01E-01 para HQ dérmica. Para crianças 2.25E-05 a 3.74E-01 para HQingestião e

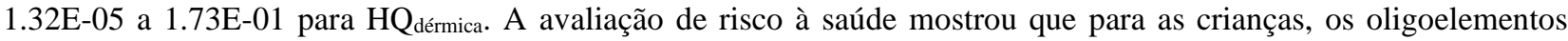
presentes na água têm um efeito potencialmente adverso na saúde não cancerígeno. Os riscos cancerígenos eram inaceitáveis para crianças e adultos. Assim, recomenda-se que o uso dessas águas seja limitado e que sejam tomadas medidas para minimizar a poluição por oligoelementos.

Palavras-chave: Poluição da água; Metal; Risco não cancerígeno; Risco de câncer; Contaminação.

\section{Resumen}

El agua es un activo importante para el mantenimiento de la vida y para el desarrollo socioeconómico. Los ambientes acuáticos han sido antropizados, recibiendo una gran carga de contaminantes, principalmente oligoelementos. Este estudio investiga la ocurrencia de riesgos para la salud causados por 15 oligoelementos en las aguas superficiales del arroyo João Leite. Los índices de riesgo para la salud se evaluaron como dosis media diaria (ADD), índice de riesgo (HQ), índice de riesgo y riesgo carcinogénico. El análisis de riesgo para la salud humana del arroyo João Leite indicó

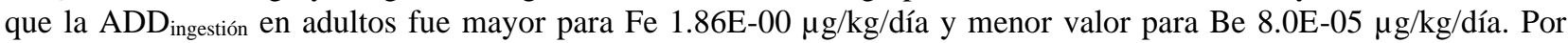
otro lado, de la $\mathrm{ADD}_{\text {dermal, }}$, el valor más alto fue para Fe $5.02 \mathrm{E}-02 \mu \mathrm{g} / \mathrm{kg} /$ día y el más bajo para $\mathrm{Sb} 1.54 \mathrm{E}-05 \mu \mathrm{g} / \mathrm{kg} / \mathrm{día}$.

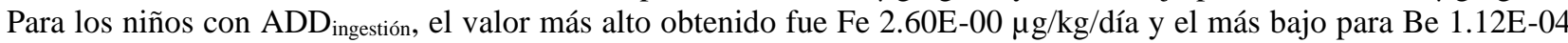

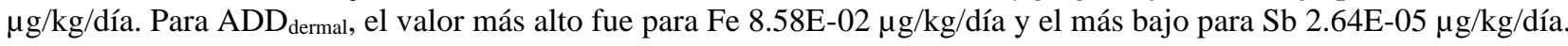
La HQ para adultos varió de 1.61E-05 a 2.97E-01 para la de HQingestión y de 7.71E-06 a 1.01E-01 para HQdermal. Para niños 2.25E-05 a 3.74E-01 para HQingestión y 1.32E-05 a 1.73E-01 para $\mathrm{HQ}_{\text {dermal. }}$ La evaluación de riesgos para la salud ha demostrado que, en el caso de los niños, los oligoelementos presentes en el agua tienen un efecto potencialmente adverso para la salud no cancerígeno. Los riesgos cancerígenos eran inaceptables para niños y adultos. Por tanto, se recomienda limitar el uso de estas aguas y tomar medidas para minimizar la contaminación por oligoelementos.

Palabras clave: Contaminación del agua; Metal; Riesgo no cancerígeno; Riesgo de cáncer; Contaminación.

\section{Introduction}

Among the pollutants in the river and stream, products with genotoxic and mutagenic potential, even in very low concentrations and in the form of complex mixtures of potentially dangerous compounds, have drawn attention concerning water quality (Roubicek et al., 2020). One of these pollutants is toxic trace elements, which can persist for long periods in water and soils, and toxic and accumulate in organisms (Kumar et al., 2020). Trace elements have carcinogenic and genotoxic mechanisms, can interact with proteins, stimulate the production of reactive oxygen species (ROS), inhibit the DNA repair system and disrupt cell proliferation (Beyersmann \& Hartwig 2008).

Due to the health effects adverse that trace elements can cause, the Environmental Protection Agency of United States (USEPA) indicates that human health risk assessment is "the process of estimating the nature and likelihood of adverse health effects in humans that may be exposed to chemicals in the contaminated environment, now or in the future". This risk assessment stipulates the identification of hazards of contaminants present in the environment, which have non-cancerous effects, which include mutagenicity, developmental toxicity, neurotoxicity and reproductive toxicity, for example, and also carcinogenic effects (Wongsasuluk et al., 2014). The risk to human health in a contaminated environment can be assessed by considering the concentration of pollutants in that location, the exposure time and the exposure degree (Zhou et al., 2020).

In this context, the objectives of this study were to estimate the risks to human health, and the non-carcinogenic and carcinogenic, with based on the ingestion and dermal contact of trace elements present in the superficial water of the stream João Leite. Reflecting in this way the great impact that can occur due to the great importance of the stream for the population that uses this aquatic system. Also, because there are no reports in the literature or previous data that demonstrate the potential risk to human health due to heavy trace elements in the selected study area, therefore being an innovation.

\section{Methodology}

This study deals with an experimental research (Köche, 2016; Pereira et al., 2018) for its methodological basement. 


\subsection{Study area and Sampling location}

The metropolitan region of Goiânia (capital of the Goiás State) is composed of 25 cities located in the Midwest region of Brazil, and has an estimated population of 7.018.354 inhabitants. The water sources of this place is are mainly supplied by the Meia Ponte river and the stream João Leite. The hydrographic basin of the stream João Leite represents an area of approximately $764 \mathrm{~km} 2$, with a total length of watercourses equal to $679.88 \mathrm{~km}$ and a length of $86 \mathrm{~km}$. Its climate, according to the Koeppen classification AW, is divided as rain station in summer and dry station in winter (Ferreira et al., 2011).

Two surface water samples were taken, one in the dry period (collect 1, in November 2017 this year the drought period was extended) and another in the rainy period (collect 2, in April 2017). In the João Leite stream, eight water samples, two samples from each location (Table 1). The water samples were collect and stored until further analysis according to Guide for the collection and conservation of water samples, sediments, aquatic communities and liquid effluents of the Environmental Company of São Paulo State (Cetesb, 2011).

Table 1. Geographic location of the sampling sites of the João Leite brook, Goiás, Brazil.

\begin{tabular}{|c|c|c|c|c|}
\hline Sampling sites & Site 1 & Site 2 & Site 3 & Site 4 \\
\hline $\begin{array}{l}\text { Geographic } \\
\text { coordinates }\end{array}$ & $\begin{array}{r}16^{\circ} 38^{\prime} 32.91 " \mathrm{~S} \\
49^{\circ} 15^{\prime} 1.97 " \mathrm{~W}\end{array}$ & $\begin{array}{l}16^{\circ} 34^{\prime} 30.54^{\prime \prime S} \\
49^{\circ} 13^{\prime} 55.02^{\prime \prime} \mathrm{W}\end{array}$ & $\begin{array}{r}16^{\circ} 28^{\prime} 25.05 " \mathrm{~S} ; \\
49^{\circ} 6^{\prime} 43.87^{\prime \prime} \mathrm{W}\end{array}$ & $\begin{array}{r}16^{\circ} 18^{\prime} 13.88^{\prime \prime S} \\
49^{\circ} 55^{\prime} 6.16^{\prime \prime W}\end{array}$ \\
\hline Main feature & $\begin{array}{r}\text { Collection of water for } \\
\text { public supply; urban área }\end{array}$ & $\begin{array}{l}\text { Altamiro de Moura Pacheco } \\
\text { ecological park; rural area }\end{array}$ & $\begin{array}{r}\text { Transition among } \\
\text { urban and rural areas }\end{array}$ & $\begin{array}{r}\text { Stretch of a highway; } \\
\text { semi-urban area }\end{array}$ \\
\hline
\end{tabular}

Source: Authors.

\subsection{Trace element analysis}

One liters of water were collect in each site to analyse the concentration metal, Dissolved Aluminum (Ald), Antimony (Sb), Arsenic (As), Barium (Ba), Beryllium (Be), Boron (B), Cadmium (Cd), Lead (Pb), Total Cobalt (Co), Dissolved Copper $(\mathrm{Cu})$, Chrome $(\mathrm{Cr})$, Dissolved Iron $(\mathrm{Fe})$, Manganese $(\mathrm{Mn})$, Nickel $(\mathrm{Ni})$ and Zinc $(\mathrm{Zn})$. The water samples were sent to Companhia Saneamento de Goiás (SANEAGO) and, were analyzed using the methods established by the Standard Methods for Examining Water and Wastewater (Clescerl et al., 1999). The samples were processed within 24 hours of collection. In which a filtration, acidification with nitric acid and digestion of the samples was carried out, later analyzed in the 710-ES inductively coupled plasma optical emission spectrometers (ICP-OESs).

\subsection{Human health risk assessment}

Based on the results obtained from the metal concentrations in the water, the risk assessment for human health will be calculated, by ingestion and dermal absorption, of the superficial waters of the João Leite stream, using the methodology and equations proposed by Means (1989) and Ilechukwu et al. (2021), with some modification. The analyzes were performed for two groups of subpopulations, adults and children separately. Considering the two routes of entry, by ingestion and dermal absorption, the average daily dose (ADD) was calculated from equation 1 and 2.

$$
\begin{aligned}
& \mathrm{ADD}_{\text {ingestion }}=\frac{C M X I X G A X E F X D}{B W X A T} \\
& \mathrm{ADD}_{\text {dermal }}=\frac{C n X S A X P X E F X D X E T X C F}{B W X A T}
\end{aligned}
$$

Where $\mathrm{ADD}$ represents the average daily dose per ingestion $\left(\mathrm{ADD}_{\text {ingestion }}\right)$ and dermal absorption $\left(\mathrm{ADD}_{\text {dermal }}\right)$ $(\mu \mathrm{g} / \mathrm{kg} / \mathrm{day}) ; \mathrm{Cm}$ is the average of the metal concentrations in the water $(\mu \mathrm{g} / \mathrm{L}) ; \mathrm{IR}$ is the rate of water intake (L/day); GA is the 
gastrointestinal absorption of said metal (\%); EF is exposure frequency (day/year); ED is the frequency of duration of exposure (year); AS is the surface area of the skin exposed (m2); Kp is the dermal permeability constant ( $\mathrm{cm} / \mathrm{h})$; ET is the exposure time (h/day); $\mathrm{CF}$ is the unit conversion factor $\left(\mathrm{L} / \mathrm{cm}^{3}\right)$; $\mathrm{Bw}$ is body weight $(\mathrm{Kg})$; $\mathrm{TA}$ is the average time (days).

\subsubsection{Non-carcinogenic analysis}

Non-carcinogenic risks to human health when exposed to heavy trace elements are described by the hazard quotient (HQ) ( $\mu \mathrm{g} / \mathrm{kg} / \mathrm{day})$, which is calculated by equation 3 and 4 .

$\mathrm{HQ} \mathrm{Q}_{\text {ingestion }}=\frac{A D D_{\text {ingmexions }}}{R f D_{\text {ingurstîn }}}$

$\mathrm{HQ}_{\text {dermal }}=\frac{A D D_{\text {derounal }}}{R f D_{\text {disturil }}}$

Where RfD is the corresponding reference dose ( $\mu \mathrm{g} / \mathrm{Kg} /$ day), of ingestion and dermal absorption.

To assess the non-carcinogenic risk of more than one exposure route for various heavy trace elements in the water, the hazard index (HI) was applied, which is the sum of the HQs of all applicable routes (equation 5).

$\mathrm{HI}=\sum_{i=1}^{m} H Q_{i}$

Where $\mathrm{i}$ is the route of exposure (ingestion and dermal absorption). HI > 1 indicates the potential for an adverse effect on human health or the need for further studies.

\subsubsection{Carcinogenic analysis}

Carcinogenic risks to human health when exposed to heavy trace elements in water are calculated by equation 6 , of the carcinogenic risk $(\mathrm{CR})$ :

$\mathrm{CR}=\mathrm{ADD} \times \mathrm{CSF}$

Where CSF is the cancer addiction factor and is defined as the risk generated by an average lifetime amount of a chemical $(\mu \mathrm{g} / \mathrm{kg} / \mathrm{day})$ carcinogenic and is specific for contaminants. USEPA indicates a range of acceptable or tolerable carcinogenic risks which are those that are $1 \times 10^{-6}$ to $1 \times 10^{-4}$ and unacceptable risks are those that go beyond $1 \times 10^{-4}$.

The input values and assumptions for the calculations of risk assessment for human health, non-cancer risk and cancer risk (equations 1, 2, 3, 4, 5 and 6) are summarized in Table 2. 
Table 2. Parameters, assumptions and input values for assessing human health risk from exposure to metals through ingestion and dermal routes.

\begin{tabular}{|c|c|c|c|c|}
\hline \multirow{3}{*}{ Parameter } & \multicolumn{4}{|c|}{ Values } \\
\hline & \multicolumn{2}{|c|}{ Ingestion } & \multicolumn{2}{|c|}{ Dermal absorption } \\
\hline & Adult & Child & Adult & Child \\
\hline Média da concentração dos metais pesados $(\mathrm{Cw})(\mu \mathrm{g} / \mathrm{L})$ & $\begin{array}{r}\text { value found in the study } \\
\text { regarding the quantification of } \\
\text { the average of each metal in } \\
\text { the water }\end{array}$ & $\begin{array}{r}\text { value found in the study } \\
\text { regarding the quantification of } \\
\text { the average of each metal in } \\
\text { the water }\end{array}$ & $\begin{array}{r}\text { value found in the study } \\
\text { regarding the quantification } \\
\text { of the average of each metal } \\
\text { in the water }\end{array}$ & $\begin{array}{r}\text { value found in the study } \\
\text { regarding the quantification } \\
\text { of the average of each metal } \\
\text { in the water }\end{array}$ \\
\hline Water intake rate (IR) (L/day) & 2 & 0,6 & - & - \\
\hline Gastrointestinal absorption of said metal (GA) (\%) & $\begin{array}{r}\text { Al 20; Sb 15; As 95; Ba 7; Be } \\
\text { 1; B 92; Cd 3; Pb 10; Co 97; } \\
\text { Cu 3; Cr 57; Fe } 20 \text { Mn 5; Ni 4; } \\
\text { Zn } 100\end{array}$ & $\begin{array}{r}\mathrm{Al} 20 ; \mathrm{Sb} 15 ; \mathrm{As} 95 ; \mathrm{Ba} 7 ; \mathrm{Be} \\
\text { 1; B 92; Cd 3; Pb 10; Co 97; } \\
\mathrm{Cu} 3 ; \mathrm{Cr} 57 ; \mathrm{Fe} 20 \mathrm{Mn} 5 ; \mathrm{Ni} 4 \\
\mathrm{Zn} 100\end{array}$ & - & \\
\hline Exposure frequency (EF) (day/year) & 365 & 365 & 365 & 365 \\
\hline Exposure duration frequency (ED) (year) & 70 & 6 & 70 & 6 \\
\hline Exposed skin surface area (AS) $\left(\mathrm{m}^{2}\right)$ & - & - & 18000 & 6600 \\
\hline Dermal permeability constant $(\mathrm{Kp})(\mathrm{cm} / \mathrm{h})$ & - & - & $\begin{array}{r}\mathrm{Al}, \mathrm{Sb}, \mathrm{AS}, \mathrm{Ba}, \mathrm{Be}, \mathrm{B}, \mathrm{Cd} \\
\mathrm{Pb}, \mathrm{Cu}, \mathrm{Cr}, \mathrm{Fe}, \mathrm{Mn}, \mathrm{Ni} 0,001 \\
\mathrm{Co} 0,0004 ; \mathrm{Zn} 0,006\end{array}$ & $\begin{array}{r}\mathrm{Al}, \mathrm{Sb}, \mathrm{AS}, \mathrm{Ba}, \mathrm{Be}, \mathrm{B}, \mathrm{Cd}, \\
\mathrm{Pb}, \mathrm{Cu}, \mathrm{Cr}, \mathrm{Fe}, \mathrm{Mn}, \mathrm{Ni} 0,001 ; \\
\mathrm{Co} 0,0004 ; \mathrm{Zn} \mathrm{0,006}\end{array}$ \\
\hline Exposure time (ET) (h/day) & - & - & 0,6 & 0,6 \\
\hline Unit conversion factor $(\mathrm{CF})\left(\mathrm{L} / \mathrm{cm}^{3}\right)$ & - & - & 0,001 & 0,001 \\
\hline Body weight $(\mathrm{Bw})(\mathrm{Kg})$ & 70 & 15 & 70 & 15 \\
\hline Average time (days) & 25550 & 2190 & 25550 & 2190 \\
\hline Corresponding reference dose (RfD) $(\mu \mathrm{g} / \mathrm{Kg} /$ day $)$ & $\begin{array}{r}\text { Al 1000; Sb 0,4; As 0,3; Ba } \\
\text { 200; Be 2; B 200; Cd 0,5; Pb } \\
\text { 1,4; Co 0,3; Cu 40; Cr 3; Fe } \\
\text { 700; Mn 140; Ni 20; Zn } 300\end{array}$ & $\begin{array}{r}\text { Al 1000; Sb 0,4; As 0,3; Ba } \\
\text { 200; Be 2; B 200; Cd 0,5; Pb } \\
\text { 1,4; Co 0,3; Cu 40; Cr 3; Fe } \\
\text { 700; Mn 140; Ni 20; Zn } 300\end{array}$ & $\begin{array}{r}\text { Al 200; As 0,285; Ba 14; B } \\
\text { 180; Cd 0,25; Pb 0,42; Co } \\
\text { 0,06; Cu 12; Cr 0,075; Fe } \\
\text { 140; Mn 0,96; Ni 0,8; Zn } 60\end{array}$ & $\begin{array}{r}\text { Al 200; As 0,285; Ba 14; B } \\
\text { 180; Cd 0,25; Pb 0,42; Co } \\
\text { 0,06; Cu 12; Cr 0,075; Fe } \\
\text { 140; Mn 0,96; Ni 0,8; Zn } 60\end{array}$ \\
\hline Cancer Inclination Factor (CSF) $(\mu \mathrm{g} / \mathrm{Kg} /$ day $)$ & $\begin{array}{r}\text { As } 2 ; \mathrm{Be} 4300 ; \mathrm{Cd} 61000 ; \mathrm{Pb} \\
8500 ; \mathrm{Cr} 41000 ; \mathrm{Ni} 840\end{array}$ & $\begin{array}{r}\text { As } 2 ; \mathrm{Be} 4300 ; \mathrm{Cd} 61000 ; \mathrm{Pb} \\
\text { 8500; Cr 41000; Ni } 840\end{array}$ & As 3660 & As 3660 \\
\hline
\end{tabular}

Source or Reference of values and assumptions: Saha et al. (2017), Shil \& Singh (2019), Mohammadi et al. (2019), Xiao et al. (2019), USEPA (2020), OEHHA (2020) and RAIS (2020). 


\subsection{Statistical analysis}

For statistical tests, StatSoft software STATISTICA® version 10.0 was used for descriptive statistics (mean and standard deviation). Student's T test for normal distributions, Wilcoxon test for other distributions. The significance level of $p<0.05$ was adopted for all analyzes.

\section{Results and Discussion}

According to Oca et al. (2020) "the nature and spatial arrangement of the materials with which water interacts are the factors that condition the composition and relative abundance of constituents in groundwater". This concept can also be extrapolated to surface waters since its composition is also represented by the interactions that surface waters undergo. However, these interactions occur in higher numbers than when compared to groundwater interactions, mainly due to being in an open environment subject to specific and non-specific variations. To assess these interactions, table 3 show the trace elements characterization, respectively, found in the samples of raw water from the stream João Leite, Goiás.

Table 3. Characterization of trace elements in the samples of raw surface water from the stream João Leite, Goiás State, Brazil.

\begin{tabular}{|c|c|c|c|c|c|c|c|c|c|}
\hline \multirow{2}{*}{ Trace elements $(\mu \mathrm{g} / \mathrm{L})$} & \multicolumn{4}{|c|}{ Dry period } & \multicolumn{4}{|c|}{ Rainy period } & \multirow{2}{*}{$\mathbf{C}_{\text {mean }}$} \\
\hline & Site 1 & Site 2 & Site 3 & Site 4 & Site 1 & Site 2 & Site 3 & Site 4 & \\
\hline $\mathrm{Al}^{\mathrm{d}}$ & 163.6 & 38.6 & 54.1 & 125.8 & 0.0 & 14.7 & 177.5 & 761.0 & 166.9 \\
\hline $\mathrm{Sb}$ & 0.0 & 0.0 & 0.0 & 0.0 & 0.2 & 0.3 & 0.2 & 0.5 & 0.1 \\
\hline As & 0.0 & 0.0 & 0.0 & 0.0 & 0.3 & 0.8 & 0.5 & 1.4 & 0.4 \\
\hline $\mathrm{Ba}$ & 54.4 & 57.3 & 49.3 & 76.4 & 53.7 & 44.8 & 63.8 & 492.0 & 111.5 \\
\hline $\mathrm{Be}$ & 0.1 & 0.1 & 0.1 & 0.1 & 0.0 & 0.0 & 0.0 & 2.5 & 0.4 \\
\hline B & 0.0 & 0.0 & 0.0 & 0.0 & 42.6 & 18.1 & 11.1 & 0.0 & 9.0 \\
\hline $\mathrm{Cd}$ & 0.1 & 0.2 & 0.3 & 0.2 & 0.3 & 0.1 & 0.2 & 2.0 & 0.4 \\
\hline $\mathrm{Pb}$ & 0.0 & 0.0 & 0.0 & 0.0 & 0.0 & 2.6 & 0.0 & 31.7 & 4.3 \\
\hline $\mathrm{Co}^{\mathrm{d}}$ & 0.0 & 0.4 & 0.0 & 1.3 & 0.0 & 0.0 & 0.0 & 19.2 & 2.6 \\
\hline $\mathrm{Cu}$ & 1.0 & 0.4 & 0.8 & 0.9 & 1.0 & 0.0 & 1.1 & 1.9 & 0.9 \\
\hline $\mathrm{Cr}$ & 5.7 & 2.7 & 4.1 & 17.8 & 3.2 & 0.8 & 6.6 & 352.4 & 49.2 \\
\hline $\mathrm{Fe}^{\mathrm{d}}$ & 197.8 & 37.7 & 374.6 & 365.3 & 127.0 & 40.3 & 783.3 & 674.9 & 325.1 \\
\hline $\mathrm{Mn}$ & 49.6 & 129.9 & 42.0 & 91.5 & 95.4 & 39.9 & 119.1 & 851.2 & 177.3 \\
\hline $\mathrm{Ni}$ & 10.4 & 3.6 & 5.4 & 8.0 & 2.7 & 1.5 & 4.0 & 124.0 & 19.9 \\
\hline
\end{tabular}

d: dissolved. Source: Authors.

Classifying the elements according to the current Brazilian legislation, CONAMA no 357 (Conama 2005), for the purpose of this stream, we have that dissolved Al, dissolved Fe and Mn can be classified in class III. According to Arantes (2017) and the purpose that this stream is used by the community, this stream should be classified as class II, however these three trace elements do not fit into this classification. Looking in isolation for each sampling point, we can classify according to the legislation the trace elements in which they can be class IV are the site 4 sample from rainy period for Al dissolved, Mn, $\mathrm{Ni}$ and $\mathrm{V}$. The metals that can be classified as class III are site 1 and 4 of dry period, and site 3 of rainy period for dissolved Al, site 4 of rainy period for $\mathrm{Pb}$, site 3 and 4 of both collections for Fe dissolved, site 2 of dry period and site 3 of rainy period for $\mathrm{Mn}$ and site 4 of rainy period for $\mathrm{Zn}$. The others are classified according to the purpose of the stream.

The metal with the highest concentration detected in the stream João Leite was Fe. Its highest value was found for site 
4 in the rainy season with $783.3 \mu \mathrm{g} / \mathrm{L}$ (Table 3). In the study of (Sarkar and Shekhar 2018) showed that the increase of iron in water could be linked to processes of oxy-reduction in nature (weathering), a microbiological activity that reducing Fe3+ to $\mathrm{Fe} 2+$, is the main source that is anthropogenic contamination, which causes anomalous growth. It is suggested that the high concentrations of Fe found agree with the authors cited; however additional studies should be carried out for this confirmation. $\mathrm{Fe}$ in high concentrations in water brings bad taste, stains, increases the growth of bacteria and increases deposition and crusting in river networks (Mehta and Srivastava 2012).

The metal Al in the dry season had its highest value for site $1(163.6 \mu \mathrm{g} / \mathrm{L})$, in the rainy season at this same point it was not detected, having its highest value for site $4(761.0 \mu \mathrm{g} / \mathrm{L})$ (Table 3). Since half of the samples had higher values than the levels acceptable by Brazilian legislation, according to the purpose of the brook, class II. High levels of Al can be due to the solubilization and weathering of this element, from soil to water, characteristic of acid tropical soils (MacHado et al., 2016; Machado et al., 2017).

The highest value for $\mathrm{Mn}$ was in the rainy season at site 4 with $851.2 \mu \mathrm{g} / \mathrm{L}$ (Table 3). The toxic metal Mn, when in the form of oxides serve as absorption or binding sites for other metals such as $\mathrm{Cd}$, Co, Ni and $\mathrm{Zn}$, and can act as natural (bio)remediation of metals (Schäffner et al., 2015). In the study of Munger et al. (2017) suggested that rivers that have dams have an increase in the concentrations of Fe and Mn. The stream João Leite has the Mauro Borges dam. This may be one of the reasons why the concentrations of Fe and $\mathrm{Mn}$ are higher than those of other metals.

The metallic element Ni had an average in the rainy period of $33.0 \mu \mathrm{g} / \mathrm{L}$ in water, due to the concentration of 124.0 $\mu \mathrm{g} / \mathrm{L}$ found on site 4 (Table 3). Ni is a source of fertilizer and can be carried by runoff into water Igbinedion \& Oguzie (2016), domestic wastewater effluents can be the main source of $\mathrm{Ni}$ pollution (Abdel-satar et al., 2017) and progress in industrialization increases Ni emissions in ecosystems (Cempel \& Nikel, 2006). These may be some of the explanations for the increased Ni concentration at site 4 .

Metal V only had a high concentration at site $4(288.5 \mu \mathrm{g} / \mathrm{L})$. Most of the pollution by $\mathrm{V}$ is in the air, by burning fossil fuels and as a result of the combustion processes used in its purification, which is emitted as oxides (VO2, V2O3, and V2O5), this can settle in the soil and sediments bodies of water. $\mathrm{V}$ in freshwater may vary depending on the difference in rainwater runoff from natural sources or industrial sources (Gummow \& Sciences, 2011).

To calculate this health risk, first the $\mathrm{ADD}_{\text {ingestion }}$ and $\mathrm{ADD}_{\text {dermal }}$ (Table 4). From the ADD, HQ and HI, were calculated for non-carcinogenic risks for adults and children by ingestion and dermal absorption described in table 4. Among the investigated metals, children and adults are more exposed and absorb more Fe, $\mathrm{Al}$ and $\mathrm{Mn}$, when compared to some of the metals with the highest detection concentration in the waters of the João Leite stream. Comparing the total group of trace

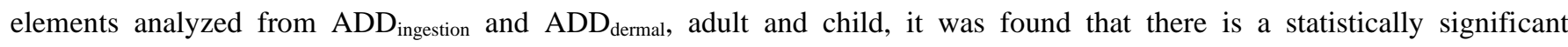
difference $(p=0.0221, p=0.0305$, respectively) among the two groups of populations, demonstrating that adults and children absorb differently, whether through gastrointestinal or dermal. HQ for adults ranged from 1.61E-05 to $2.97 \mathrm{E}-01$ for HQingestion and 7.71E-06 to 1.01E-01 for $\mathrm{HQ}_{\text {dermal }}$. For children 2.25E-05 to 3.74E-01 for HQingestion and 1.32E-05 to $1.73 \mathrm{E}-01$ for $\mathrm{HQ}$ dermal (Table 4). The HI referring to Co (2.43E-01 adult; 3.41E-01 child) and Cr (3.68E-01 adult; 5.47E-01 child) (Table 4) is not >1 to indicates a potential for an adverse effect on human health, however the values are close to 1 , it is a warning sign. The HI sum of all metals was 7.08E-01 for adult and 1.04E+00 for child, indicating that for children the metals present in the water of the stream João Leite have a potential adverse effect on non-carcinogenic health, since total HI is $>1$. HI for adults followed the trend of $\mathrm{Cr}>\mathrm{Co}>\mathrm{As}>\mathrm{Mn}>\mathrm{Pb}>\mathrm{Ni}>\mathrm{Zn}>\mathrm{Cd}>\mathrm{Fe}>\mathrm{Ba}>\mathrm{B}>\mathrm{Al}>\mathrm{Cu}$ and for child $\mathrm{Cr}>\mathrm{Co}>\mathrm{Mn}>\mathrm{As}>\mathrm{Pb}>\mathrm{Ni}>$ $\mathrm{Zn}>\mathrm{Cd}>\mathrm{Fe}>\mathrm{Ba}>\mathrm{B}>\mathrm{Al}>\mathrm{Cu}$. 
Table 4. Values of the average daily dose and non-cancerous human health risks from metals in the water of the stream João Leite, Goiás State, Brazil, for adults and children.

\begin{tabular}{|c|c|c|c|c|c|c|c|c|c|c|}
\hline \multirow[b]{2}{*}{ 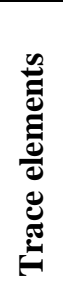 } & \multicolumn{5}{|c|}{ Adult } & \multicolumn{5}{|c|}{ Child } \\
\hline & 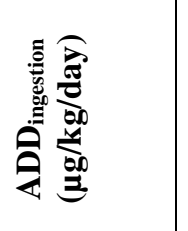 & 恶焉 & 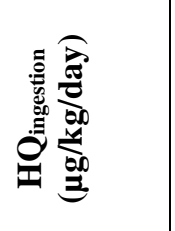 & 产 & 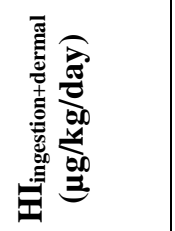 & 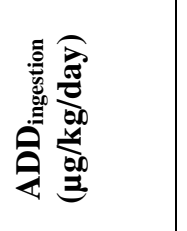 & 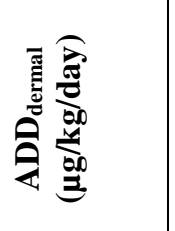 & 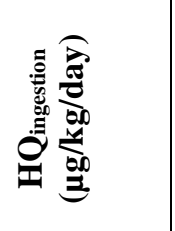 & 重 & 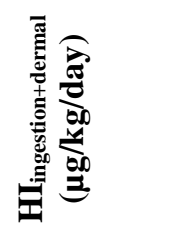 \\
\hline $\mathrm{Al}$ & $9.54 \mathrm{E}-01$ & $2.58 \mathrm{E}-02$ & 9.54E-04 & $1.29 \mathrm{E}-04$ & $1.08 \mathrm{E}-03$ & $1.34 \mathrm{E}+00$ & 4.41E-02 & $1.34 \mathrm{E}-03$ & $2.20 \mathrm{E}-04$ & $1.56 \mathrm{E}-03$ \\
\hline $\mathrm{Sb}$ & $4.29 \mathrm{E}-04$ & $1.54 \mathrm{E}-05$ & $1.07 \mathrm{E}-03$ & - & - & $6.00 \mathrm{E}-04$ & $2.64 \mathrm{E}-05$ & $1.50 \mathrm{E}-03$ & - & - \\
\hline As & $1.09 \mathrm{E}-02$ & $6.17 \mathrm{E}-05$ & $3.62 \mathrm{E}-02$ & $2.17 \mathrm{E}-04$ & $3.64 \mathrm{E}-02$ & $1.52 \mathrm{E}-02$ & $1.06 \mathrm{E}-04$ & $5.07 \mathrm{E}-02$ & $3.71 \mathrm{E}-04$ & $5.10 \mathrm{E}-02$ \\
\hline $\mathrm{Ba}$ & $2.23 \mathrm{E}-01$ & $1.72 \mathrm{E}-02$ & $1.12 \mathrm{E}-03$ & $1.23 \mathrm{E}-03$ & $2.34 \mathrm{E}-03$ & $3.12 \mathrm{E}-01$ & 2.94E-02 & $1.56 \mathrm{E}-03$ & $2.10 \mathrm{E}-03$ & $3.66 \mathrm{E}-03$ \\
\hline $\mathrm{Be}$ & $8.00 \mathrm{E}-05$ & $6.17 \mathrm{E}-05$ & 4.00E-05 & - & - & $1.12 \mathrm{E}-04$ & $1.06 \mathrm{E}-04$ & $5.60 \mathrm{E}-05$ & - & - \\
\hline B & $2.37 \mathrm{E}-01$ & $1.39 \mathrm{E}-03$ & $1.18 \mathrm{E}-03$ & $7.71 \mathrm{E}-06$ & 1.19E-03 & $3.31 \mathrm{E}-01$ & $2.38 \mathrm{E}-03$ & $1.66 \mathrm{E}-03$ & $1.32 \mathrm{E}-05$ & $1.67 \mathrm{E}-03$ \\
\hline $\mathrm{Cd}$ & $2.86 \mathrm{E}-04$ & $6.17 \mathrm{E}-05$ & $5.71 \mathrm{E}-04$ & $2.47 \mathrm{E}-03$ & $3.04 \mathrm{E}-03$ & $4.00 \mathrm{E}-04$ & $1.06 \mathrm{E}-04$ & $8.00 \mathrm{E}-04$ & $4.22 \mathrm{E}-03$ & $5.02 \mathrm{E}-03$ \\
\hline $\mathrm{Pb}$ & $1.23 \mathrm{E}-02$ & $6.63 \mathrm{E}-04$ & $8.78 \mathrm{E}-03$ & $1.58 \mathrm{E}-03$ & $1.04 \mathrm{E}-02$ & $1.72 \mathrm{E}-02$ & $1.14 \mathrm{E}-03$ & $1.23 \mathrm{E}-02$ & $2.70 \mathrm{E}-03$ & $1.50 \mathrm{E}-02$ \\
\hline Co & $7.21 \mathrm{E}-02$ & $1.60 \mathrm{E}-04$ & $2.40 \mathrm{E}-01$ & $2.67 \mathrm{E}-03$ & $2.43 \mathrm{E}-01$ & $1.01 \mathrm{E}-01$ & $2.75 \mathrm{E}-04$ & $3.36 \mathrm{E}-01$ & $4.58 \mathrm{E}-03$ & $3.41 \mathrm{E}-01$ \\
\hline $\mathrm{Cu}$ & $6.43 \mathrm{E}-04$ & $1.39 \mathrm{E}-04$ & $1.61 \mathrm{E}-05$ & $1.16 \mathrm{E}-05$ & $2.76 \mathrm{E}-05$ & $9.00 \mathrm{E}-04$ & $2.38 \mathrm{E}-04$ & $2.25 \mathrm{E}-05$ & $1.98 \mathrm{E}-05$ & $4.23 \mathrm{E}-05$ \\
\hline $\mathrm{Cr}$ & $8.01 \mathrm{E}-01$ & 7.59E-03 & 2.67E-01 & $1.01 \mathrm{E}-01$ & $3.68 \mathrm{E}-01$ & $1.12 \mathrm{E}+00$ & $1.30 \mathrm{E}-02$ & $3.74 \mathrm{E}-01$ & $1.73 \mathrm{E}-01$ & $5.47 \mathrm{E}-01$ \\
\hline $\mathrm{Fe}$ & $1.86 \mathrm{E}+00$ & $5.02 \mathrm{E}-02$ & $2.65 \mathrm{E}-03$ & $3.58 \mathrm{E}-04$ & $3.01 \mathrm{E}-03$ & $2.60 \mathrm{E}+00$ & $8.58 \mathrm{E}-02$ & $3.72 \mathrm{E}-03$ & $6.13 \mathrm{E}-04$ & $4.33 \mathrm{E}-03$ \\
\hline $\mathrm{Mn}$ & $2.53 \mathrm{E}-01$ & $2.74 \mathrm{E}-02$ & $1.81 \mathrm{E}-03$ & $2.85 \mathrm{E}-02$ & $3.03 \mathrm{E}-02$ & $3.55 \mathrm{E}-01$ & $4.68 \mathrm{E}-02$ & $2.53 \mathrm{E}-03$ & $4.88 \mathrm{E}-02$ & $5.13 \mathrm{E}-02$ \\
\hline $\mathrm{Ni}$ & $2.27 \mathrm{E}-02$ & $3.07 \mathrm{E}-03$ & $1.14 \mathrm{E}-03$ & $3.84 \mathrm{E}-03$ & $4.98 \mathrm{E}-03$ & $3.18 \mathrm{E}-02$ & $5.25 \mathrm{E}-03$ & $1.59 \mathrm{E}-03$ & $6.57 \mathrm{E}-03$ & $8.16 \mathrm{E}-03$ \\
\hline $\mathrm{Zn}$ & $1.18 \mathrm{E}+00$ & $3.83 \mathrm{E}-03$ & $3.94 \mathrm{E}-03$ & $6.39 \mathrm{E}-05$ & $4.01 \mathrm{E}-03$ & $1.66 \mathrm{E}+00$ & $6.56 \mathrm{E}-03$ & $5.52 \mathrm{E}-03$ & $1.09 \mathrm{E}-04$ & $5.63 \mathrm{E}-03$ \\
\hline
\end{tabular}

ADD: Average daily dose; HQ: hazard ratio; HI: hazard index. - : not calculated as it had no reference value for the corresponding dermal reference dose. Source: Authors. 
In the study of Ferré-Huguet et al. (2009) found HI higher in children than in adults, which was also found by Sánchez-Mateos et al. (2020), which indicated that children have a higher non-carcinogenic risk, developing some disease as a result of being more vulnerable and having less tolerance to trace elements.

In the Ambato River, in Ecuador, $\mathrm{Cr}$ was the metal with the highest non-carcinogenic risk studied for ingestion (Sánchez-Mateos et al., 2020). This corroborates with this study since $\mathrm{Cr}$ was the second metal with the highest HI in this study. Co was the metal with the highest HI, despite being biologically crucial as a component of vitamin B12, with excessive consumption, it can induce neurological, cardiovascular and endocrine deficits (Leyssens et al., 2017). In the study of Ma et al. (2016) did not find HI of trace elements > 1 and indicated that trace elements, even if they do not pose non-cancerous risks to human health, the presence of these can be toxic to health, and highlights that the conventional toxicity thresholds must be updated for the risk index thresholds. The last authors confirm what our study is suggesting.

The carcinogenic risk values throughout life were calculated (Table 5). $\mathrm{CR}_{\text {dermal }}$ for As was 2.26E-01 and 3.86E-01, for adults and children, respectively, one being considered an unacceptable risk. The $\mathrm{CR}_{\text {ingestion }}$ followed the decreasing trend of $\mathrm{Cr}>\mathrm{Pb}>\mathrm{As}>\mathrm{Ni}>\mathrm{Cd}>\mathrm{Be}$, for both populations studied, demonstrating an unacceptable cancer risk, for all studied trace elements. The metallic compounds ( $\mathrm{As}, \mathrm{Cd}, \mathrm{Cr}, \mathrm{Co}, \mathrm{Pb}, \mathrm{Hg}$ and $\mathrm{Ni}$ ) are carcinogenic, their mechanisms of tumor formation are not well understood. The main hypothesis due to oxidative stress that causes homeostasis imbalance and the production of free radicals, as well as interfering with the detoxification system. All of these events cause DNA damage, lipid peroxidation, protein modification (Koedrith \& Seo 2011).

As obtained an unacceptable cancer risk for both ingestion and dermal contact. Toxic metal As is a carcinogenic, it can cause various health effects, among them, skin manifestations (black foot disease, hypopigmentation, keratosis), reproductive disorder, immune deficiency, diseases (cardiovascular, hematological, renal, neurological and respiratory) and cancer (bladder, kidney, liver, lungs, skin and prostate). The harmful effects of As affect all age groups, making it difficult to remove them from the environment, but whenever possible, it should be eradicated in drinking water and food crops (Joardar et al., 2020).

$\mathrm{Cr}$ was the potentially toxic metal with the highest $\mathrm{CR}_{\text {ingestion. }}$. The $\mathrm{Cr}$ performs the common cellular process of toxic elements due to oxidative stress, DNA damage, apoptosis and cell death, also its cations have a strong affinity for sulfur, which is present in proteins, thus being able to deactivate, interrupt or alter the metabolic processes (Yaman, 2020).

The river Mahananda in West Bengal and Bangladesh, indicated that the CR of the river was unacceptable, and its highest CR rate is 8.2E-04 (Shil \& Singh 2019). In the Atuwara River in Nigeria, the CR of the trace elements found in the water ranged from 4.62E-3 to $1.01 \mathrm{E}-1$ for adults and from $2.11 \mathrm{E}-4$ to $4.96 \mathrm{E}-2$ for children, indicating that 1 in 10 adults and 1 in every 20 children may suffer from cancer throughout their lives exposed to river waters (Emenike et al., 2020). Comparing with the result of table 4, the CR values for trace elements were much higher, which may suggest that the João Leite waters may induce the risk of cancer throughout the life of the exposed population. 
Table 4. Values of carcinogenic health risks arising from metals in the water of the stream João Leite, Goiás State, Brazil, for adults and children.

\begin{tabular}{|c|c|c|c|c|}
\hline \multirow{2}{*}{ Trace elements } & \multicolumn{2}{|c|}{ Adult } & \multicolumn{2}{|l|}{ Child } \\
\hline & $\mathbf{C R}_{\text {ingestion }}$ & $\mathbf{C R}_{\text {dermal }}$ & $\mathbf{C R}_{\text {ingestion }}$ & $\mathbf{C R}_{\text {dermal }}$ \\
\hline As & $1.03 \mathrm{E}+02$ & $2.26 \mathrm{E}-01$ & $1.44 \mathrm{E}+02$ & $3.86 \mathrm{E}-01$ \\
\hline $\mathrm{Be}$ & $3.44 \mathrm{E}-01$ & - & $4.82 \mathrm{E}-01$ & - \\
\hline $\mathrm{Cd}$ & $1.74 \mathrm{E}+00$ & - & $2.44 \mathrm{E}+00$ & - \\
\hline $\mathrm{Pb}$ & $1.04 \mathrm{E}+02$ & - & $1.46 \mathrm{E}+02$ & - \\
\hline $\mathrm{Cr}$ & $3.29 \mathrm{E}+04$ & - & $4.60 \mathrm{E}+04$ & - \\
\hline $\mathrm{Ni}$ & $1.91 \mathrm{E}+01$ & - & $2.67 \mathrm{E}+01$ & - \\
\hline
\end{tabular}

CR: carcinogenic risk. Source: Authors.

In the study of Rehman et al. (2018) found results for surface water in the vicinity of the Sewakht mines in Pakistan, in which he indicated the likelihood of cancer and non-cancer and indicated that this water should not be used for drinking purposes. Similarly, it is suggested that the water of Leite ribeirrão is not used for drinking purposes. It also suggests that the primary contact recreation such as swimming, diving and water skiing, is avoided due to the RC for The have been considered unacceptable.

\section{Conclusion}

The decreasing trend in the concentration of trace elements in water samples from João Leite stream was $\mathrm{Fe}>\mathrm{Mn}>$ $\mathrm{Al}>\mathrm{Ba}>\mathrm{Cr}>\mathrm{Zn}>\mathrm{Ni}>\mathrm{B}>\mathrm{Pb}>\mathrm{Co}>\mathrm{Cu}>\mathrm{Be}>\mathrm{Cd}>\mathrm{As}>\mathrm{Sb}$, not following the same trend for carcinogenic risk that had its highest value for $\mathrm{Cr}$ and $\mathrm{Pb}$, and non-cancerous with the highest values for $\mathrm{Co}$ and $\mathrm{Cr}$. The non-cancer risk associated with trace elements was evaluated and verified for children who use water from João Leite stream. Carcinogenic risk has been demonstrated, both in children and adults. It has been reported as an unacceptable risk, demonstrating the high risk associated with ingestion and dermal contact with water from the João Leite stream and its potential to cause cancer throughout life due to pollution by trace elements. Finally, the results shown in this study demonstrate with a scientific basis the verification of pollution and its effects on the consumer population of the João Leite stream. The importance of public policies for monitoring, management and use, in addition to actions for the recovery, preservation and maintenance of the João Leite stream, is highlighted here. Given the importance that this water system has for approximately 1 million people, directly and indirectly, who use it for consumption, supply for human consumption, primary contact recreation, irrigation of vegetables and fruit plants, park and gardens and others with which the public may have direct contact, aquaculture and fishing activity. Mainly the riverside population that is vulnerable to health risk due to contamination by trace elements in which this surface water is used for survival. New work and research must be carried out to minimize pollution by trace elements, as well as its possible effects on the health of the population in aquatic environments.

\section{Acknowledgments}

My sincere thanks to the Companhia de Saneamento de Goiás (SANEAGO), for making some results. My thanks also to the Coordination for the Improvement of Higher Education Personnel (CAPES), the State of Goiás Research Support Foundation (FAPEG) and the National Council for Scientific and Technological Development (CNPq). 


\section{References}

Abdel-satar, A. M., Ali, M. H., \& Goher, M. E. (2017). Indices of water quality and metal pollution of Nile. The Egyptian Journal of Aquatic Research, 43(1), 21-29. https://doi.org/10.1016/j.ejar.2016.12.006

Arantes, A. G. S. (2017). Abastecimento público do ribeirão joão leite - go. https://repositorio.bc.ufg.br/tede/handle/tede/7808

Beyersmann, D., \& Hartwig, A. (2008). Carcinogenic metal compounds: Recent insight into molecular and cellular mechanisms. Archives of Toxicology, 82(8), 493-512. https://doi.org/10.1007/s00204-008-0313-y

Cempel, M., \& Nikel, G. (2006). Nickel : A Review of Its Sources and Environmental Toxicology. 15(3), 375-382.

Cetesb (Companhia Ambiental do Estado de São Paulo). (2011). Guia Nacional de Coleta e Preservação de Amostras - Água, Sedimento, Comunidades Aquáticas e Efluentes Líquidos. Companhia Ambiental Do Estado de São Paulo, 326p. https://doi.org/C737g

Clescerl, L., Greenberg, A., \& Eaton, A. (1999). Standard Methods for Examining Water and Wastewater.

Conama (Conselho Nacional do Meio Ambiente). (2005). Resolução n 357, 18 de março de 2005. Diário Oficial, 053 , $58-63$.

Emenike, P. G. C., Neris, J. B., Tenebe, I. T., Nnaji, C. C., \& Jarvis, P. (2020). Estimation of some trace metal pollutants in River Atuwara southwestern Nigeria and spatio-temporal human health risks assessment. Chemosphere, 239, 124770. https://doi.org/10.1016/j.chemosphere.2019.124770

Ferré-Huguet, N., Nadal, M., Schuhmacher, M., \& Domingo, J. L. (2009). Human health risk assessment for environmental exposure to metals in the Catalan stretch of the Ebro River, Spain. Human and Ecological Risk Assessment, 15(3), 604-623. https://doi.org/10.1080/10807030902892604

Ferreira, J. C., Pais, M. S., Yamanaka, K., Carrijo, G. A., Teixeira, M. B., Silva, R. T. da, \& Rabelo, C. G. (2011). Previsão de vazão da bacia do ribeiro joão leite utilizando redes neurais artificiais. Botucatu Irriga, 16(3), 339-350. https://doi.org/10.1017/CBO9781107415324.004

Gummow, B., \& Sciences, B. (2011). Vanadium : Environmental Pollution and Health Effects. 628-636.

Igbinedion, J. J., \& Oguzie, F. A. (2016). Heavy Metals Concentration in Fish and Water of River Osse Benin City Nigeria. 4(3), 80-84. https://doi.org/10.12691/ijebb-4-3-2

Ilechukwu, I., Osuji, L. C., Okoli, C. P., Onyema, M. O., \& Ndukwe, G. I. (2021). Assessment of heavy metal pollution in soils and health risk consequences of human exposure within the vicinity of hot mix asphalt plants in Rivers State, Nigeria. Environmental Monitoring and Assessment, 193, 461 (2021). https://doi.org/10.1007/s10661-021-09208-6

Joardar, M., Das, A., Mridha, D., Nilanjana, A. De, \& Chowdhury, R. (2020). Evaluation of Acute and Chronic Arsenic Exposure on School Children from Exposed and Apparently Control Areas of West Bengal , India. Exposure and Health, 0123456789. https://doi.org/10.1007/s12403-020-00360-x

Köche, J. C. (2016). Fundamentos de metodologia científica. Editora Vozes.

Koedrith, P., \& Seo, Y. R. (2011). Advances in Carcinogenic Metal Toxicity and Potential Molecular Markers. International Journal of Molecular Sciences, 12(12), 9576-9595. https://doi.org/10.3390/ijms12129576

Kumar, V., Sharma, A., Kumar, R., Bhardwaj, R., Kumar Thukral, A., \& Rodrigo-Comino, J. (2020). Assessment of heavy-metal pollution in three different Indian water bodies by combination of multivariate analysis and water pollution indices. Human and Ecological Risk Assessment, 26(1), 1-16. https://doi.org/10.1080/10807039.2018.1497946

Leyssens, L., Vinck, B., Van Der Straeten, C., Wuyts, F., \& Maes, L. (2017). Cobalt toxicity in humans-A review of the potential sources and systemic health effects. Toxicology, 387(March), 43-56. https://doi.org/10.1016/j.tox.2017.05.015

Ma, X., Zuo, H., Tian, M., Zhang, L., Meng, J., Zhou, X., Min, N., Chang, X., \& Liu, Y. (2016). Assessment of heavy metals contamination in sediments from three adjacent regions of the Yellow River using metal chemical fractions and multivariate analysis techniques. Chemosphere, 144, 264-272. https://doi.org/10.1016/j.chemosphere.2015.08.026

MacHado, C. S., Alves, R. I. S., Fregonesi, B. M., Tonani, K. A. A., Martinis, B. S., Sierra, J., Nadal, M., Domingo, J. L., \& Segura-Muñoz, S. (2016), Chemical Contamination of Water and Sediments in the Pardo River, São Paulo, Brazil. Procedia Engineering, 162, 230-237. https://doi.org/10.1016/j.proeng.2016.11.046

Machado, C. S., Fregonesi, B. M., Alves, R. I. S., Tonani, K. A. A., Sierra, J., Martinis, B. S., Celere, B. S., Mari, M., Schuhmacher, M., Nadal, M., Domingo, J. L., \& Segura-Muñoz, S. (2017). Health risks of environmental exposure to metals and herbicides in the Pardo River, Brazil. Environmental Science and Pollution Research, 24(25), 20160-20172. https://doi.org/10.1007/s11356-017-9461-z

Means, B. (1989). Risk-assessment guidance for superfund. Volume 1. Human health evaluation manual. Part A. Interim report (Final) (U. S. E. P. Agency (ed.); Office of).

Mehta, B. C., \& Srivastava, K. K. (2012). Iron in ground water in india and its geochemistry. Indian Society of Applied Geochemists Memoir, 1, 227-240

Mohammadi, A. A., Zarei, A., Majidi, S., Ghaderpoury, A., Hashempour, Y., Saghi, M. H., ... \& Ghaderpoori, M. (2019). Carcinogenic and non-carcinogenic health risk assessment of heavy metals in drinking water of Khorramabad, Iran. MethodsX, 6, 1642-1651. https://doi.org/10.1016/j.mex.2019.07.017

Munger, Z. W., Shahady, T. D., \& Schreiber, M. E. (2017). Effects of reservoir stratification and watershed hydrology on manganese and iron in a damregulated river. Hydrological Processes, 31(8), 1622-1635. https://doi.org/10.1002/hyp.11131 
Oca, R. M. G. F.-M. de, Ramos-Leal, J. A., Morán-Ramírez, J., Esquivel-Martínez, J. M., Álvarez-Bastida, C., \& Fuentes-Rivas, R. M. (2020). Hydrogeochemical Characterization and Assessment of Contamination by Inorganic and Organic Matter in the Groundwater of a Volcano-Sedimentary Aquifer. Bulletin of Environmental Contamination and Toxicology. https://doi.org/10.1007/s00128-020-02819-8

OEHHA (Office of Environmental Health Hazard Assessment). (2020). Toxicity criteria on chemicals evaluated by OEHHA.https://oehha.ca.gov/chemicals. Pereira, A. S., Shitsuka, D. M., Parreira, F. J., \& Shitsuka, R. (2018). Metodologia da pesquisa científica.[e-book].

RAIS (Risk Assessment Information Systemrais). (2020). The Risk Assessment Information System: Toxicity profiles. https://rais.ornl.gov/tools/tox_profiles.html

Rehman, I. ur, Ishaq, M., Ali, L., Khan, S., Ahmad, I., Ud, I., \& Ullah, H. (2018). Ecotoxicology and Environmental Safety Enrichment , spatial distribution of potential ecological and human health risk assessment via toxic metals in soil and surface water ingestion in the vicinity of Sewakht mines, district Chitral, Northern Pakistan. Ecotoxicology and Environmental Safety, 154(February), 127-136. https://doi.org/10.1016/j.ecoenv.2018.02.033

Roubicek, D. A., Rech, C. M., \& Umbuzeiro, G. A. (2020). Mutagenicity as a parameter in surface water monitoring programs—opportunity for water quality improvement. Environmental and Molecular Mutagenesis, 61(1), 200-211. https://doi.org/10.1002/em.22316

Saha, N., Rahman, M. S., Ahmed, M. B., Zhou, J. L., Ngo, H. H., \& Guo, W. (2017). Industrial metal pollution in water and probabilistic assessment of human health risk. Journal of environmental management, 185, 70-78. https://doi.org/10.1016/j.jenvman.2016.10.023

Sánchez-Mateos, S., Pérez, L. V., Córdova Suárez, M. A., \& Cabrera-Riofrio, D. A. (2020). Heavy metal contamination in the Cotopaxi and Tungurahua rivers: a health risk. Environmental Earth Sciences, 79(6), 1-14. https://doi.org/10.1007/s12665-020-8869-9

Sarkar, A., \& Shekhar, S. (2018). Iron contamination in the waters of Upper Yamuna basin. Groundwater for Sustainable Development, 7(July 2017), 421429. https://doi.org/10.1016/j.gsd.2017.12.011

Schäffner, F., Merten, D., Pollok, K., Wagner, S., Knoblauch, S., Langenhorst, F., \& Büchel, G. (2015). Fast formation of supergene Mn oxides/hydroxides under acidic conditions in the oxic/anoxic transition zone of a shallow aquifer. Environmental Science and Pollution Research, 22(24), 19362-19375. https://doi.org/10.1007/s11356-015-4404-z

Shil, S., \& Singh, U. K. (2019). Health risk assessment and spatial variations of dissolved heavy metals and metalloids in a tropical river basin system. Ecological Indicators, 106, 105455. https://doi.org/10.1016/j.ecolind.2019.105455

Usepa (United States Environmental Protection Agenc). (2020). Human Health Risk Assessment. https://www.epa.gov/risk/human-health-risk-assessment.

USEPA (United States Environmental Protection Agenc). (2020). Human Health Risk Assessment. https://www.epa.gov/risk/human-health-risk-assessment

Wongsasuluk, P., Chotpantarat, S., Siriwong, W., \& Robson, M. (2014). Heavy metal contamination and human health risk assessment in drinking water from shallow groundwater wells in an agricultural area in Ubon Ratchathani province, Thailand. Environmental Geochemistry and Health, 36(1), 169-182. https://doi.org/10.1007/s10653-013-9537-8

Xiao, J., Wang, L., Deng, L., \& Jin, Z. (2019). Characteristics, sources, water quality and health risk assessment of trace elements in river water and well water in the Chinese Loess Plateau. Science of the Total Environment, 650, 2004-2012. https://doi.org/10.1016/j.scitotenv.2018.09.322

Yaman, B. (2020). Health Effects of Chromium and Its Concentrations in Cereal Foods Together with Sulfur. Exposure and Health, 12(2), 153-161. https://doi.org/10.1007/s12403-019-00298-9

Zhou, Y., Ning, J., Li, L., Long, Q., Wei, A., \& Liu, Z. (2020). Health Risk Assessment of Groundwater in Gaobeidian , North China : Distribution , Source , and Chemical Species of the Main Contaminants. Exposure and Health, 12(3), 427-446. https://doi.org/10.1007/s12403-020-00365-6 